Old Dominion University

ODU Digital Commons

Communication \& Theatre Arts Faculty

Publications

Communication \& Theatre Arts

2019

\#MeToo and the Politics of Collective Healing: Emotional

Connection as Contestation

Allison Page

Jacquelyn Arcy

Follow this and additional works at: https://digitalcommons.odu.edu/communication_fac_pubs

Part of the Communication Technology and New Media Commons, Critical and Cultural Studies

Commons, Mass Communication Commons, Social Media Commons, and the Women's Studies

Commons 
ORIGINAL ARTICLE

\title{
\#MeToo and the Politics of Collective Healing: Emotional Connection as Contestation
}

\author{
Allison Page ${ }^{1}$ \& Jacquelyn Arcy ${ }^{2}$ \\ 1 Department of Communication and Theatre Arts, Institute for the Humanities, Old Dominion University, \\ Norfolk, VA 23508, USA \\ 2 Department of Communication, University of Wisconsin-Parkside, Kenosha, WI 53141, USA
}

\begin{abstract}
Participants in the \#MeToo movement on Twitter expressed emotions like rage, pain, and solidarity in their personal accounts of sexual violence. This article explores the digital circulation of these affects and considers how the outpouring of tweets about sexual harassment and abuse contribute to a feminist politics centered on collective healing. The particular emotions expressed in the \#MeToo Twitter archive subvert the logics of quantification and visibility that undergird popular feminism and the attention economy, and produce an affective excess that works toward movement founder Tarana Burke's original project of "mass healing." At a moment wherein popular feminism emphasizes individual empowerment and consumption, and carceral feminism relies on criminalization and incarceration, the \#MeToo movement's focus on shared emotions represents the potential for a feminist politics rooted in collective support and restorative justice.
\end{abstract}

Keywords: Affect, Race, Feminist Media Studies, Hashtag Activism, Restorative Justice, Popular Feminism, Carceral Feminism

doi:10.1093/ccc/tcz032

\section{Prioritizing punishment means that we keep patriarchy firmly in place. (Mariame Kaba, Open Society, 2018)}

In 2006, Tarana Burke first used Me Too to create solidarity among survivors of sexual violence, developing her vision of "empowerment through empathy" specifically to support fellow survivors of color. Emphasizing the intersections between racialized and gendered violence, Burke began the Me Too movement to address the lack of support resources for survivors of color, particularly in the U.S. south. For Burke, the affective potential of connecting survivors to one another uses "the

Corresponding author: Allison Page; e-mail: apage@odu.edu, Jacquelyn Arcy; e-mail: arcy@uwp.edu 
power of empathy to stomp out shame" and, further, addresses sexual violence as an epidemic that cannot be solved through momentary spurts of public attention and outcry (Goodman, 2017).

More than a decade later, the viral spread of the \#MeToo hashtag began in October 2017 in response to a tweet by white actress Alyssa Milano, soliciting widespread documentation of the extent of sexual violence: "If all the women and men who have been sexually harassed, assaulted or abused wrote 'me too' as a status, we might give people a sense of the magnitude of the problem. \#metoo." Within the first 24 hours, there were more than 12 million social media posts from people using the hashtag to share personal stories of abuse and harassment, and to convey words of support for survivors (CBS, 2017). By the end of 2017, there were over 6.5 million tweets with the hashtag (Chou, 2018). In an unsurprising maneuver-occluding and expunging the work of women of color-media sources were quick to credit Milano and other white, female celebrities with founding the movement, erasing Burke's efforts and initial vision. Feminist and antiracist activists have raised concerns about the erasure of Burke and other women of color from the \#MeToo movement (Burch, 2017; Donegan, 2018; Goodman, 2017; Hubbard, 2017; Rottenberg, 2017). We share this critique, and are thus interested in theorizing how the particular emotions expressed on digital media_including rage, pain, and solidarity - work toward Burke's original project of mass healing and ending sexual violence through a restorative approach that does not bolster the prison-industrial complex (Fessler, 2018).

In this article, we argue that the affective economy of \#MeToo aligns with Burke's ongoing vision by focusing on collective healing and care. \#MeToo participants engaging in emotional care work-affective labor done in service to others-have created digital support networks that provide a foundation for a politics of care that is antithetical to a punishment model reliant on surveillance, policing, and imprisonment, which destroys communities, sidelines survivors, and devalues healing (Mansbach, 2012; Rentschler, 2014; Tronto, 1993). The caring labor involved in these ephemeral exchanges fosters connection and support: feelings that are crucial to healing. We define a politics of care as a transformative and holistic framework that attends to, rather than erases, the emotional aspects of survivorship and creates a foundation for restorative justice. We therefore see the collective expression of rage, pain, and solidarity as a potential tool for building a politics of care that could supersede a reliance on the state and the logics of incarceration.

The \#MeToo movement, therefore, suggests an alternative to popular and carceral feminisms, which dominate digital spaces and contemporary feminist politics (Schwedel, 2017). Emphasizing individual empowerment and visibility over collectivity and structural change, popular feminism, which has flourished alongside "popular misogyny," predominantly views consumer culture as the locus of resistance (Banet-Weiser, 2015). Unsurprisingly, \#MeToo has been commodified-there are MeToo necklaces to accompany tote bags bearing slogans about empowermentand used to justify punitive measures akin to carceral feminism, which is a strand of feminism that relies on and collaborates with the carceral state and promotes 
incarceration, surveillance, and increased policing as a feminist solution to sexual and gender violence (Kim, 2018). Neither formation emphasizes collective care nor centers healing, both of which are central to restorative justice. By contrast, the \#MeToo movement's focus on healing and connection twists the digital attention economy's logics of quantification and visibility in ways that exceed capital. To be sure, the public displays of trauma and resilience rely on the tools of the attention economy (for example, using hashtags to link tweets). Yet, \#MeToo's focus on collective healing subverts the logics of communicative capitalism by offering a model to address sexual violence that is not rooted in consumer culture and the prison-industrial complex. Of course, the \#MeToo movement does not exist outside of the exploitation of gendered digital labor and the erasure of differences between survivors based on social categories including race, sexuality, and class; it often privileges the experiences of white women based in the global north. \#MeToo tweets also exist within the corporate, technological structure of Twitter: a platform capable of removing posts and charging users with "terms of use" violations. As Shenila Khoja-Moolji (2015, p. 350) points out, feminist hashtag activism can form a "tenuous collectivity" that frequently reproduces white, liberal feminism. While we focus on the potentialities of the \#MeToo movement, we are simultaneously attentive to the forces of white supremacy, imperialism, and capitalism.

\section{Feminism within communicative capitalism}

Although survivors of sexual violence have long shared their stories, the mass disclosure of personal experiences on social media has exponentially amplified their voices. This is due, in part, to the economic structure of social media platforms, which aim to keep users tuned in to a continuous stream of unpaid, user-generated content alongside paid advertisements. The very design of social media platforms encourages constant engagement through features such as liking, sharing, commenting, and hashtag links that aggregate trending topics. The \#MeToo movement was propelled by these technological features and its participatory call for survivors of sexual violence to add their voices to the chorus of people saying, "me too." In this instance, social networks like Twitter extend the reach of \#MeToo narratives and produce affective excesses that motivate more posts and further circulation.

The interactive nature of contemporary digital media and its emphasis on participation constituted a shift in media culture that has paved the way for hashtag activism and coincided with the rise of what Jodi Dean (2009, p. 2) calls "communicative capitalism." As Dean identifies, the celebratory discourse of the Internet-considered full of emancipatory potential due to its supposed open access for all-disregarded its corporate structure and imbrication with capitalism. But beyond that, Dean highlight how late capitalism relies on communication: information is a central commodity in circulation, which aligns with an attention economy that thrives on the transfer of information and data. The "smidgeon of attention" produced by each tweet, click, like, and share is part of what Dean (2010, p. 95-6) calls the "affective flow" of the Internet, 
which ensnares us in a continuously moving river of information and affect that urges us to enjoy and produces anxiety that we are not "enjoying enough, as much, or as well as others are." Any possible resistance to the logics of late capitalism is swept up in the endless movement, the ongoing drive of capital. Critically, social media work as key contributors to the circulation of affect. In the never-ending flow of communication, a surplus of affect is produced for each moment—each tweet or share-enabling a slight pause before becoming caught up once again in the wave. According to Dean (2010, p. 95-6), the resulting "affective networks" are not productive of actual community but, rather, feelings of community that "circulate intensities we might trace."

But what of these feelings of community? Although we find Dean's theorization of how information is productive for capital to be a useful framework for making sense of social media's operations, we suggest that this framework isn't sufficient for understanding the affective circuits that \#MeToo produced and in which it circulated. Beyond the scope of \#MeToo and its capture of a large slice of digital space-however fleeting - we see possibility in a feminist project that, at its best, was not about reifying and strengthening the carceral state, which is inextricable from late capitalism. Even if it is evanescent, we suggest that there is an affective surplus with \#MeToo that contains a feminist vision that does not seek the political or liberation within consumer culture or the state.

To be clear, we are not suggesting that \#MeToo is outside of communicative capitalism. Social media campaigns and hashtag activism more broadly support the economic imperative of social media platforms and, thus, fall under Dean's understanding of how the Internet operates. At the same time, however, we contend that theorizing the specific affective dimensions of \#MeToo sheds light on feminist models of care that are survivor-focused, community-building, and geared toward healing. In other words, the affects circulating around \#MeToo suggest a feminist politics of care that responds to popular feminism. For Sarah Banet-Weiser (2018b), popular feminism (and its emphasis on so-called empowerment through visibility, consumer culture, and an engagement with the state) is in the cultural zeitgeist, made mainstream by celebrities like Beyoncé. Critically, this "mainstreaming of feminism" supplants collective activism and struggle, "as if seeing or purchasing feminism and contributing to its visibility is the same thing as doing something-something that might effectively change the patriarchal structure of our society" (Banet-Weiser, 2018a). The rise of popular feminism cannot be detached from hashtag activism and the attention economy, nor from the Black feminist and queer politics of Black Lives Matter, against which it operates in contrast.

If we hold \#BlackLivesMatter (BLM) as part of a larger context for \#MeToo, we can more readily see the affective economies in which both hashtags (and the movements they engendered) circulate. What BLM demonstrates is that the BLM hashtag was an encapsulation of an affective project, one grounded in collective struggle: Alicia Garza describes her initial use of "black lives matter" as a "love letter to black folks," and all three of the women who started BLM are activists and organizers with longstanding commitments to social justice (Garza and Kauffman, 2015). As many scholars and 
activists have observed, BLM's power is derived in part because it expresses a demand and conveys a sentiment-love-while also being both present and future-oriented (Bailey and Leonard, 2015). Similarly, \#MeToo offers an entry point into solidarity, with survivors supporting one another, rendering it survivor-focused rather than offender-focused. Of course, the risk of bolstering carceral and white feminisms remains ever-present; it is thus crucial to follow the lead of feminists of color toward a politics that does not ultimately strengthen the carceral state and white supremacy.

In other words, \#MeToo offers a basis for restorative justice through its emphasis on centering survivors and care, rather than punishment; simply put, this is a prerequisite for establishing alternative modes of justice and reparation. These are not new ideas, and scholars and activists working on prison abolition, in particular, have long theorized a world where justice does not equal incarceration (Davis, 2016; Gilmore, 2007; Maree Brown, 2017). By looking to the state, carceral feminism seeks solutions to gender-based and sexual violence at the very site of violence for many, including people of color, trans and queer people, and poor people. Carceral logics inform and uphold rape culture: as such, the prison will never undo it. Yet as Ruth Wilson Gilmore (2007) makes plain, prison abolition requires forging new ways of being, not just abolishing old ones. The values of restorative justice-including care, repair, and healing-are the same that infuse the ways that \#MeToo has been taken up online. In its current iteration, \#MeToo is not an example of restorative justice, but rather contributes to an emotional framework required of alternatives to carcerality by centering care and healing. According to anti-prison activist Vicki Law (Open Society Foundation, 2018, p. 15), the "criminal punishment system" is incapable of addressing healing "because the survivor has nothing to do with it." \#MeToo is thus one small slice of a much larger cultural shift needed to transform justice.

\section{Politicizing emotional labor}

Social media is often understood as respite from the routine of work, serving as distraction and compensation from the pain and drudgery of laboring under capitalism. One of social media's promises is that it is a space where we can "be ourselves" and make intimate connections with people all over the world. But as many scholars have identified, social media interactivity is work that produces immense value for media companies (Andrejevic, 2008; Terranova, 2000), and as feminists have long argued, work is delegated and valued based on gender (Federici, 2008; Hartmann, 1979). Recent scholarship in feminist media studies has explored how large swaths of gendered social media activities-posting new outfits on Instagram, selling craft goods on Etsy, creating makeup tutorials on YouTube, sharing recipes and childrearing tips on Pinterest-remain entrenched within historically constructed modes of femininity, centered on domestic, reproductive, and care work (Duffy, 2017; Ouellette and Wilson, 2011; Pham, 2015).

Though the \#MeToo movement has drawn attention to the ubiquity of sexual violence, it has simultaneously demanded an exponential amount of feminized 
emotional and digital labor. This labor ranges from sharing private and painful stories about sexualized and gendered harassment; reading (and relating to) countless stories of assault and abuse; and feminists of color explaining patriarchy and white supremacy. For Eldering and Risam (2018), the labor involved in the \#MeToo movement raises the question "of why recognizing the extent of sexual violence requires the public performance of affective digital labor, of pain, grief, anger, and sadness on social media," particularly given the juxtaposition between the prevalence of sexual violence and the "sense of extraordinariness that the volume of affective performance on \#metoo provoked." The telling of these stories is a form of digitally mediated and feminized emotional labor, rooted in traditional notions of "women's work" that situate women as experts in the intimate realms of emotions and care work.

Feminized emotional labor is often derided and dismissed, yet we see it as a potential tool for political change. Feminist Marxist scholars and activists have argued that women's unwaged domestic labor has provided the foundation for capitalism by reproducing the labor force and producing capital (Federici, 2012). International campaigns like "Wages for Housework," which sought remuneration for domestic labor in the 1970s, specifically highlighted the productivity of care work in maintaining the workforce. In this way, activists recognized the political potential of their domestic labor.

In the field of affect studies, critical-cultural scholars concerned with the political capacities of emotions have coalesced around two central questions: how do emotions affect individual subject formation, and how might they produce or sustain collective political engagement? Bringing together these two threads, we theorize emotions as potentialities that may spur recognition and lead to new forms of collective agency. We begin with Kathleen Stewart's (2007) premise that affects are "ordinary." As intensities circulate through everyday encounters, Stewart suggests, they co-construct our individual experiences and sense of feeling in common. Sara Ahmed's (2004a) economic model of emotions demonstrates how affect constitutes a collective, by moving and sticking temporarily to subjects and objects. For Ahmed (2004a, p. 119), emotions are more than psychic dispositions; they "mediate the relationship between the psychic and the social." Put differently, emotions connect the individual's inner psyche to socially constructed forces and make collective critique possible. The flow of affect between intimate experiences and public sentiment, Stewart (2007, p. 2) adds, creates new "modes of knowing, relating, and attending to" collective structures of feeling.

The circulation of emotions through media adds another dimension to the politicization of feelings and their capacity to affect socio-political change. In some cases, Jennifer Petersen (2011) explains, mass media texts can be imbued with ideological messages that teach viewers how to feel and, ultimately, shape public perception and policy. However, Sasha Torres' (2010) work on media representations of torture in the post-9/11 era shows that affective intensities are not so easily channeled. In fact, emotions often exceed governing rationalities in ways that open up space for critique. 
Social media platforms expand this potentiality by connecting broad and disparate audiences and circumventing the gatekeeping power of mainstream media outlets.

In an era where our affective capacities are subsumed under capitalism and made an essential part of work (Gregg, 2011; Hochschild, 1983; Illouz, 2007), \#MeToo participants' deployment of care outside the domestic sphere and the needs of the market is ripe with political potential. Thus, we view the affective dimensions of \#MeToo as connected to a longer history of feminist efforts to revalue and politicize care work. In particular, the affective labor involved in expressing anger, pain, and solidarity on social media provids a sense of community and "feeling in common" that serves collective healing. Further, by creating a public archive of emotional responses to trauma-what Ann Cvetkovich (2003, p. 465) calls a "trauma culture"participants forge "ways of living" and "structures of feeling" that provide emotional justice for sexual trauma. These efforts support a feminist politics-led by women of color-beyond incarceration and the state, privileging care and restorative forms of healing and justice (Lober, 2018).

\section{"36 'MeToo' tweets that will shatter you"}

The explosion of \#MeToo social media posts in October 2017 coincided with several high-profile cases of sexual abuse in Hollywood, including the 84 women who accused producer Harvey Weinstein of sexual harassment and assault. Unlike mainstream media outlets, social media provided a platform for anyone to document and share their experiences, and led to unprecedented visibility for those participating in hashtag activism. The \#MeToo content from so-called ordinary people that circulated widely on social media-but that was outside of the parameters of commercially saleable stories-is where we focus our analysis.

In part, the enormity of \#MeToo's archive yielded a journalistic fixation on both the sheer number of tweets and the vast range of experiences. One Bustle article, in particular, synthesized common themes by categorizing tweets according to sentiment and purpose. Titled "36 'MeToo' Tweets That Will Shatter You," the article highlighted and echoed the emotional economy in which MeToo circulated and, by framing the experience of reading the tweets in terms of emotion-devastation, especially-the article further underscored the emotional labor of engaging with such an archive of trauma (Busch, 2017). To explore the affective excess of the \#MeToo movement, we took the 36 tweets collected by Bustle as a microcosm of the emotions circulated by participants. Bustle is an online magazine targeting millennial women, and had 50 million monthly users at the time (Segran, 2016). We selected this publication because it embodied the tenets of popular feminism: it was created by a white, male tech investor to profit off of highly commodified images of (mostly white) female empowerment. In this way, the affective excess of the \#MeToo movement that exists beyond consumption is brought into sharp focus as a juxtaposition to Bustle: a paradigmatic example of popular feminism. We focus on this particular article because it centered the quotidian experiences of social media users who identified 
common themes related to sexual violence. Most of the tweets in the collection were from users with unverified accounts, meaning that they had not been marked as public figures by Twitter. Still, these \#MeToo tweets garnered thousands of comments, likes, and retweets on average. Rather than representing an exhaustive list of \#MeToo posts, our aim was to explore how the sentiments engendered through \#MeToo can provide the basis of a feminist politics centered on collective care.

\section{Anger}

The particular emotions expressed in \#MeToo posts often cut through the rhetoric of popular and carceral feminisms. For instance, the public and collective expression of emotions like rage and grief subverts the dominant social logic that women and people of color, in particular, should hide these emotions or allay them through consumption or carceral institutions (Cooper, 2018; Gay, 2016; Traister, 2018). As such, the public display of rage engendered by \#MeToo formed a key part of its affective significance. Although sites like Hollaback, which tracks street harassment and provides a forum to share experiences of violence in public space, offer a digital repository for anger, \#MeToo's vast scope and reach rendered it unique, especially in the varieties of anger expressed and by whom: anger about the freezing of actress Rose McGowan's Twitter account (Romano, 2017); anger about the racist obfuscation and erasure of Tarana Burke and women and girls of color by white feminists; anger about how very quotidian gendered violence is; and anger about the emotional costs and effects of outrage during the Trump era. For instance, one Twitter user described her anger in terms of the ubiquity of sexual violence: "Know what makes me angry? That my 1st thought about this movement was, 'But isn't that *all* of us?' \& my 2nd was 'Which time?' \#MeToo" (Hodges, 2017). The comments on her post are revealing, and include responses from women expressing both heartbreak ("this tweet made me start crying") and connection ("I did find comfort in reading your status and knowing it wasn't just myself who thought this"), and sometimes both: "Your comment actually made me have to hold back tears. I felt the same way. \#FuckingAwful\#WhenCanThisShitStopHappeningToWomen\#Its2017” (Hodges, 2017).

Certainly, feminist rage is not new; however, the anger circulated and produced by \#MeToo posts and re-tweets offered a first step to identifying sexual violence as worthy of outrage, particularly when it has otherwise been so normalized. Supporting and commiserating with others' anger is intense affective labor: work that recognizes and legitimizes the source of that anger. Acceptable or productive forms of anger are mostly reserved for white men, who are not often shamed, disciplined, or rejected for being angry. The anger animating \#MeToo offered an affective sensibility for those who might instead individualize the systemic pervasiveness of sexual violence. In other words, given that anger is racialized and gendered, with only some constructed as able to have it (much less express it), the production, acknowledgement, and circulation of collective anger through \#MeToo's digital archive of sexual violence provided a space for rage. There is possibility and potentiality when survivors- 
particularly people of color, queer people, and women-are collectively angry. Rage is generative, especially when combined with a politics of healing.

\section{Pain}

Many of the \#MeToo participants also expressed pain in relation to their personal experiences with sexual violence and the collective trauma of others. At first glance, these feelings appear to support popular feminism's emphasis on empowering the individual to overcome oppression. However, the digital linking of these testimonies through the \#MeToo hashtag forces a recognition of the mutuality of trauma. As such, one of the \#MeToo movement's key contributions to popular discourses on sexual violence was a sense that affective connection provides a path to overcoming pain and trauma.

The process of bearing witness to others' pain-evidenced in likes, shares, and comments-is a form of collective care work that facilitates conversations about healing. According to Ahmed (2004b, p. 28), pain is a feeling that "attaches us to others." Although pain is an individual experience, Ahmed (2004b, p. 29) suggests that it creates mutuality through the process of disclosing and recognizing one another's pain. Twitter users echoed this sentiment by suggesting "we are all here and we all are surviving” (A Proper Tease, 2017). For Ahmed (2004b, p. 30-31), the ethical response to pain is "being open to being affected" by the unknowable pain of others and taking action on their behalf. \#MeToo participants engaged in this transformative praxis by witnessing and responding to others' pain.

The process of writing and reading testimonies, and creating community around pain, evidenced the political potential of the \#MeToo movement. Rather than circulating sexual assault stories as strategies for empowerment or punitive justice, \#MeToo participants sat with each other's suffering; as the Bustle article suggested, the archive of \#MeToo tweets will "shatter you." On the whole, social media responses to \#MeToo accounts were not voyeuristic or shaming, but rather a collective coming together of survivors offering support and tools for healing.

Describing the impact of \#MeToo, Twitter user Paula (2017) wrote, "Best Thing: Finding out we are not alone and have all dealt with this. Worst Thing: Finding out we have all dealt with this \#MeToo." Despite her rage at the number of people affected by sexual violence, Paula suggested that there was solace to be found in communicating with other survivors. In response to Paula's original post (which received 581 retweets and 2,191 likes as of August 2018), others expressed their heartbreak and grief over the scale of sexual violence. For instance, @KeelyMcelroy responded: "I sit here scrolling through the posts and cry-for myself \& others. I'm glad I am not aloneWish I was." Notably, this Twitter user expressed her pain not only as an individual emotion, but as a broader "structure of feeling": this is Raymond Williams' (1977) term to describe patterns of feeling that emerge within and in response to a particular social and historical context. Many \#MeToo participants described how the collective pain expressed in \#MeToo posts moved them toward anger and action. As one user 
wrote: "It's breaking my [broken heart emoji] how many \#MeToo I see trending by women who have been victims of sexual assault. This shit has got to stop!" (Siskind, 2017).

Indeed, much of the \#MeToo archive is comprised of advice and support for other survivors. Twitter user Shannon Taylor (2017) offered words of encouragement: "It's been 5 years since I have been raped. To fellow survivors: You will -Trust again -Love again -Feel safe again -Be you again \#MeToo." Other survivors, like Peace2Day (2017) provided support: "Our experiences, while unique share traumasending healing prayers of strength and compassion." By recognizing the specificity of individual experiences alongside their shared pain, \#MeToo participants created affective connections that exceeded and resisted the dominant logics of capitalism and carceral feminism. The structure of feeling that circulated within the \#MeToo movement conveyed the sense that solidarity and support can replace shame and sadness, and lead to collective healing.

\section{Solidarity}

Many of the \#MeToo posts channeled emotions like anger and pain into a call for solidarity among survivors. The caring labor of believing others' accounts of sexual harassment and abuse is a critical component of building solidarity within the movement. Although there is a long history of feminist appeals to believe survivors of sexual and domestic violence in the face of institutionalized denial, the \#MeToo movement brought this mantra into the mainstream and reinforced a sense of collectivity that has often been elided in contemporary, popular feminism. On Twitter, it became common to see people respond to \#MeToo testimonials with messages of support and belief, even for those who did not share their experiences online, as evidenced by Bindas Ladki (2017), who posted: "If you aren't okay w posting \#MeToo, know this: 1. I believe you. 2. You don't have to speak up to be brave. Living in the after is brave." The space for collective politics was thus widened by inviting all survivors into the movement, and not only the participants who had contributed public accounts. The call to believe survivors was particularly powerful in the face of legal institutions that have historically disbelieved survivors of sexual violence.

Within the \#MeToo movement, there have been widespread efforts to challenge institutions like law enforcement, the legal system, medical providers, academic administrations, and employers that disbelieve survivors of sexual violence. Accounts of sexual harassment in the workplace have an unsurprising similarity: survivors are often young women targeted by older, male employers. \#MeToo participants recounted experiences of inappropriate touching (Cannabitch, 2017), being pinned against a wall (Dugas, 2017), and verbal abuse at work, like a 36-year-old coworker who told a 17-year-old girl he was going to "spank [her] for being a naughty girl" (Daisy, 2017). Survivors who reported sexual abuse to the police described experiences like being called a liar and being talked out of pressing charges (Busch, 
2017). Many survivors reported feeling scared to report sexual violence for fear of retaliation, not being believed, and being blamed or shamed. "Sexual assault is handled so poorly," one Twitter user wrote, "that it's easier to convince yourself that it didn't actually happen. \#metoo" (Ash, 2017). The swell of stories about the abuse perpetrated within social institutions and the systemic failure of governing institutions to protect victims indicated the extent to which survivors were turning away from dominant discourses about reporting and litigating sexual violence, and turning toward each other for healing.

For women of color, these institutional failures were not new. The voices of Black women and girls-particularly regarding sexualized, racial violence-have often been absent from mainstream, white, feminist movements: erased and denied by a racially gendered order and hierarchy of value. Instead, Danielle McGuire (2018, p. 70) explains, Black women have historically relied on an "oral tradition" to warn friends and family "about the dangers that awaited them in white spaces." The \#MeToo movement did not refigure this history-as underscored by the emphasis on white actresses-but the ostensibly open architecture of the Internet provided a new, public realm to circulate these accounts. The simplicity of saying "me too" in a digital, public forum offered a point of entry for anyone affected by sexual violence and promoted a sense of solidarity among survivors. The phrase itself inserts the individual"me"-into the collective. In this sense, the \#MeToo movement's approach to sexual violence privileged survivors' experiences over dominant narratives of victimization and punishment.

\section{Conclusion}

During a 5 July 2018 speech at a Montana rally, Donald Trump publicly mocked the \#MeToo movement against sexual violence and harassment. Describing his racialized fantasy of testing the veracity of Senator Elizabeth Warren's (Democrat, Massachusetts) indigenous heritage, Trump joked that he would toss her a DNA kit, "but we have to do it gently because we're in the \#MeToo generation, so we have to be very gentle" (Sonmez, 2018). Given his long and well-documented misogyny, Trump's derisive use of \#MeToo to rally his followers was unsurprising; indeed, Trump's remarks signified the contradictions of our moment, where an openly white supremacist and misogynist president in the white House exists in tandem with widespread disclosures of sexual violence and harassment. Given that unabashed misogyny is rife in the highest echelons of state power, it is revealing that the emotion of shock continues to have such purchase around sexual violence. Angela Davis questioned in 1981 how it was that anyone could be shocked by the magnitude of sexual violence. As Jessie Kindig (2018, p. 18) writes, "the language of shock, of exposé, of surprise misleadingly identifies the specific event as the problem. The shock then and now is that the violence is quotidian." In this way, \#MeToo used the affective space of the Internet, per Dean's argument, to recirculate shock. 
Yet this collective shock was also accompanied by a witnessing that extended care and support to survivors through the production of the digital archive. If we attend to race, gender, and sexuality in an analysis of capitalism, the labor of care is also visible. Within this context, the affective excesses of the \#MeToo movement-using social media to make visible collective feelings of rage, pain, and solidarity-suggest a departure from popular feminism's emphasis on individual empowerment and consumption and from carceral feminism's reliance on the state and incarceration. As critiques of carceral feminism have gained broader traction in recent years, the devastations of U.S. mass incarceration (often brought to light by BLM activists and prison abolitionists) have become harder to ignore. There is potential in this public display of trauma and resilience, wherein a feminist politics of support and restorative justice could supplant a reliance on the state and its carceral logics.

\section{Acknowledgments}

The authors thank Brittany Farr for her exceptional, close reading and helpful feedback on an early draft. They thank the two anonymous reviewers for their thoughtful and rigorous comments and suggestions.

\section{References}

Ahmed, S. (2004a). Affective economies. Social Text, 79, 117-139. doi:10.1215/01642472-22-2_79-117

Ahmed, S. (2004b). The cultural politics of emotion. New York, NY: Routledge.

Andrejevic, M. (2008). Watching television without pity: The productivity of online fans. Television \& New Media, 9(1), 24-46. doi:10.1177/1527476407307241

Ash [awkward4lyfe]. (2017). Sexual assault is handled so poorly that it's easier to convince yourself that it didn't actually happen. \#metoo [Tweet]. Retrieved from https://twitter. com/awkward4lyfe?ref_src=twsrc\%5Etfw\%7Ctwcamp\%5Etweetembed\%7Ctwterm \%5E919732282746966021\&ref_url=https\%3A\%2F\%2Fwww.bustle.com\%2Fp\%2F36me-too-tweets- that-will-shatter-you- 2920220

Bailey, J., \& Leonard, D. (2015). Black lives matter: Post-nihilistic freedom dreams. Journal of Contemporary Rhetoric, 5, 67-77.

Banet-Weiser, S. (2015). Popular misogyny: A zeitgeist. Culture Digitally, Retrieved from http://culturedigitally.org/2015/01/popular-misogyny-a-zeitgeist/

Banet-Weiser, S. (2018a). Popular feminism: \#MeToo. Los Angeles Review of Books. Retrieved from https://lareviewofbooks.org/article/popular-feminism-metoo/

Banet-Weiser, S. (2018b). Popular feminism: Structural rage. Los Angeles Review of Books. Retrieved from https://lareviewofbooks.org/article/popular-feminism-structural-rage/\#

Burch, A. (2017). The \#MeToo moment: After Alabama, Black women wonder, what's next? In The New York Times. Retrieval URL: https://www.nytimes.com/2017/12/14/us/themetoo-moment-after-alabama-black-women-wonder-whats-next.html.

Busch, M. (2017). 36 "Me Too" tweets that will shatter you. Bustle. Retrieved from https:// www.bustle.com/p/36-me-too-tweets-that-will-shatter-you-2920220 
Cannabitch [tender_buds]. (2017). The owner of the first company I worked for felt it was appropriate to rub my shoulders whike I worked \& called me baby. I was 17. \#MeToo [Tweet]. Retrieved from https://twitter.com/tender_buds/status/919740449262223361?ref_src= twsrc\%5Etfw\%7Ctwcamp\%5Etweetembed\%7Ctwterm\%5E919740449262223361\&ref_ url=https\%3A\%2F\%2Fwww.bustle.com\%2Fp\%2F36-me-too-tweets-that-will-shatteryou- 2920220

CBS News. (2017). More than 12M Me Too Facebook posts, comments, reactions in 24 hours. Retrieved from https://www.cbsnews.com/news/metoo-more-than-12-millionfacebook-posts-comments-reactions-24-hours/

Chou, S. (2018). Millions say \#MeToo. But not everyone is heard equally. Public Radio International. Retrieved from https://www.pri.org/stories/2018-01-23/millions-say-metoo-noteveryone-heard-equally.

Cooper, B. (2018). Eloquent rage: A Black feminist discovers her superpower. New York, NY: St. Martin's Press.

Cvetkovich, A. (2003). An archive of feelings: Trauma, sexuality, and lesbian public cultures. Durham, NC: Duke University Press.

Daisy [spideyhollandx]. (2017). At 16, my 36 year old co-worker told me he was gonna "spank me for being a naughty girl" I stayed silent because I was scared \#MeToo [Tweet]. Retrieved from https://twitter.com/spideyhollandx/status/919743711357087744

Davis, A. (2016). Freedom is a constant struggle: Ferguson, Palestine, and the foundations of a movement. Chicago, IL: Haymarket Books.

Dean, J. (2009). Democracy and other neoliberal fantasies: Communicative capitalism and left politics. Durham, NC: Duke University Press.

Dean, J. (2010). Blog theory: Feedback and capture in the circuits of drive. Malden, MA: Polity Press.

Donegan, M. (2018). How \#MeToo revealed the central rift within feminism today. The Guardian. Retrieved from https://www.theguardian.com/news/2018/may/11/howmetoo-revealed-the-central-rift-within-feminism-social-individualist

Duffy, B. (2017). (Not) getting paid to do what you love: Gender, social media, and aspirational work. New Haven, CT: Yale University Press.

Dugas, K. [boho_travel]. (2017). My supervisor asked me to step into the bathroom so he could show me how to do the inventory. He pinned me against a wall. \#MeToo [Tweet]. Retrieved from https://twitter.com/boho_travel/status/919745736824315904?ref_src=twsrc\%5Etfw \%7Ctwcamp\%5Etweetembed\%7Ctwterm\%5E919745736824315904\&ref_url=https\%3A \%2F\%2Fwww.bustle.com\%2Fp\%2F36-me-too-tweets-that-will-shatter-you- 2920220

Eldering, C., \& Risam, R. (2018). Introduction: A gathering of feminist perspectives on digital labor. First Monday, 23. Retrieved from. http://journals.uic.edu/ojs/index.php/fm/article/ view/8278/6646. doi:10.5210/fm.v23i3.8278

Federici, S. (2008). Precarious labor: A feminist viewpoint. Retrieved from https:// inthemiddleofthewhirlwind.wordpress.com/precarious-labor-a-feminist-viewpoint/

Federici, S. (2012). Revolution at point zero: Housework, reproduction, and feminist struggle. Oakland, CA: PM Press.

Fessler, L. (2018). Tarana Burke, creator of me too, believes you don't have to sacrifice everything for a cause. Quartz. Retrieved from https://qz.com/work/1193569/me-toomovement-creator-tarana-burke-says-you-dont-have-to-sacrifice-everything-for-acause/ 
Garza, A., \& Kauffman, L. (2015). A love note to our folks: Alicia Garza on the organizing of Black Lives Matter. N+ 1 Magazine. Retrieved from https://nplusonemag.com/onlineonly/online-only/a-love-note-to-our-folks/

Gay, R. (2016). Who gets to be angry? The New York Times. Retrieved from https://www. nytimes.com/2016/06/12/opinion/sunday/who-gets-to-be-angry.html

Gilmore, R. (2007). Golden gulag: Prisons, surplus, crisis, and opposition in globalizing California. Los Angeles, CA: University of California Press.

Goodman, A. (2017). \#MeToo founder Tarana Burke, Alicia Garza of Black Lives Matter on wave of sexual harassment reports. Democracy Now! Retrieved from https://www. democracynow.org/2017/11/24/metoo_founder_tarana_burke_alicia_garza

Gregg, M. (2011). Work's intimacy. Cambridge, MA: Polity Press.

Hartmann, H. (1979). The unhappy marriage of Marxism and feminism: Towards a more progressive union. Capital \& Class, 3(2), 1-33. doi:10.1177/030981687900800102

Hochschild, A. (1983). The managed heart: Commercialization of human feeling. Berkeley, CA: University of California Press.

Hodges, J. [KresyTalk]. (2017). Know what makes me angry? That my 1st thought about this movement was, "But isn't that *all* of us?" \& my 2nd was "Which time?" \#MeToo [Tweet]. Retrieved from https://twitter.com/KresyTalk/status/919768699149565953?ref_src=twsrc \%5Etfw\%7Ctwcamp\%5Etweetembed\%7Ctwterm\%5E919768699149565953\&ref_url= https $\% 3 \mathrm{~A} \% 2 \mathrm{~F} \% 2 \mathrm{~F}$

Hubbard, S. (2017). Russell Simmons, R. Kelly, and why Black women can't say \#MeToo. The New York Times. Retrieved from https://www.nytimes.com/2017/12/15/opinion/russellsimmons-black-women-metoo.html

Illouz, E. (2007). Cold intimacies: The making of emotional capitalism. Cambridge, England: Polity Press.

Khoja-Moolji, S. (2015). Becoming an "intimate publics": Exploring the affective intensities of hashtag feminism. Feminist Media Studies, 15, 347-350. doi:10.1080/14680777.2015.1008747

Kim, M. (2018). From carceral feminism to transformative justice: Women-of-color feminism and alternatives to incarceration. Journal of Ethnic and Cultural Diversity in Social Work, 27, 219-233. doi:10.1080/15313204.2018.1474827

Kindig, J. (2018). Where freedom starts: Sex, power, violence, \#MeToo, a Verso report. In Verso, Books (Ed.) Introduction. Brooklyn, NY: Verso.

Ladki, B. [bindasladki] (2017). If you aren't okay w posting \#MeToo, know this: 1. I believe you. 2. You don't have to speak up to be brave. Living in the after is brave. [Tweet]. Retrieved from https://twitter.com/bindasladki/status/919744918641434626?ref_src=twsrc\%5Etfw \%7Ctwcamp\%5Etweetembed\%7Ctwterm\%5E919744918641434626\&ref_url=https\%3A \%2F\%2Fwww.bustle.com\%2Fp\%2F36-me-too-tweets-that-will-shatter-you-2920220

Lober, B. (2018). (Re)thinking sex positivity, abolition feminism and the \#MeToo movement: Opportunity for a new synthesis. Abolition Journal. Retrieved from. https:// abolitionjournal.org/rethinking-sex-positivity-abolition-feminism-metoo-movementopportunity-new-synthesis/.

Mansbach, D. (2012). The strategic use of the politics of care: The Israeli checkpoint watch movement. Feminist Theory, 13(1), 43-58. doi:10.1177/1464700111429905

Maree Brown, A. (2017). Emergent strategy: Shaping change, changing worlds. Chico, CA: AK Press. 
McGuire, D. (2018). The maid and Mr. Charlie: Rosa Parks and the struggle for Black women's bodily integrity. In Verso Books (Ed.), Where freedom starts: Sex, power, violence, \#MeToo, a Verso Report. In Verso. Brooklyn, NY.

Open Society Foundation. (2018). Righting carceral feminism's wrongs in a \#MeToo era. [Transcript]. Retrieved from https://www.opensocietyfoundations.org/events/rightingcarceral-feminism-s-wrongs-metoo-era.

Ouellette, L., \& Wilson, J. (2011). Women's work. Cultural Studies, 25(4-5), 548-565. doi:10.1080/09502386.2011.600546

Paula [therealpaulah]. (2017). Best thing: Finding out we are not alone and have all dealt with this Worst Thing: Finding out we have all dealt with this \#MeToo. [Tweet]. Retrieved from https://twitter.com/therealpaulah/status/919740074610364416?ref_src=twsrc\%5Etfw \%7Ctwcamp\%5Etweetembed\%7Ctwterm\%5E919740074610364416\&ref_url=https\%3A $\% 2 \mathrm{~F} \% 2 \mathrm{~F}$

Petersen, J. (2011). Murder, the media, and the politics of public feelings: Remembering Matthew Shepard and James Byrd Jr. Bloomington. IN: Indiana University Press.

Pham, M. (2015). Asians wear clothes on the Internet: Race, gender, and the work of personal style blogging. Durham, NC: Duke University Press.

Rentschler, C. (2014). Rape culture and the feminist politics of social media. Girlhood Studies, 7(1), 65-82. doi:10.3167/ghs.2014.070106

Romano, N. (2017). Rose McGowan's Twitter suspended after Harvey Weinstein, Ben Affleck Tweets. EW.com. https://ew.com/movies/2017/10/12/rose-mcgowan-twitter-suspendedharvey-weinstein-ben-affleck/

Rottenberg, C. (2017). Can \#MeToo go beyond white neoliberal feminism? Who can say \#MeToo and who will be heard? Al Jazeera. Retrieved from https://www.aljazeera.com/ indepth/opinion/metoo-white-neoliberal-feminism-171213064156855.html

Segran, E. (2016). The women behind the new bustle on reinventing "women's media." Fast Company. Retrieved from https://www.fastcompany.com/3063755/exclusive-the-womenbehind-the-new-bustle- on-reinventing-womens-media

Schwedel, H. (2017). The jewelry designer who is already selling \#MeToo necklaces explains herself. Slate. Retrieved from http://www.slate.com/articles/technology/technology/2017/ 10/the_jewelry_designer_who_s_selling_metoo_necklaces_online_explains_herself. html

Siskind, A. [Amy_Siskind]. (2017) It's breaking my heart how many \#MeToo I see trending by women who have been victims of sexual assault. This shit has got to stop! \#WomenWhoRoar. [Tweet]. Retrieved from https://twitter.com/Amy_Siskind/status/ 919656389269688327?ref_src=twsrc\%5Etfw\%7Ctwcamp\%5Etweetembed\%7Ctwterm \%5E919656389269688327\&ref_url=https\%3A\%2F\%2F

Sonmez, F. (2018). Trump mocks \#MeToo movement in Montana rally. The Washington Post, Retrieved from. https://www.washingtonpost.com/politics/trump-mocks-metoomovement-in-montana-rally/2018/07/05/fad40ce2-80b3-11e8-b660-4d0f9f0351f1_ story.html?utm_term $=.9 \mathrm{~b} 6 \mathrm{~b} 346 \mathrm{a} 70 \mathrm{fa}$.

Stewart, K. (2007). Ordinary affects. Durham, NC: Duke University Press.

Taylor, S. [HeyThereImShan]. (2017). It's been 5 years since I have been raped. To fellow survivors: You will -Trust again-Love again-Feel safe again -Be you again \#MeToo. [Tweet]. Retrieved from https://twitter.com/HeyThereImShan/status/919738677630300162 
Terranova, T. (2000). Free labor: Producing culture for the digital economy. Social Text, 18(2), 33-58. doi:10.1215/01642472-18-2_63-33

Torres, S. (2010). Televising Guantanamo: Transmissions of feeling during the Bush years. In Staiger, J., Cvetkovich, A., Reynolds, A. (Eds.), Political emotions. Austin, TX: University of Austin Press.

Traister, R. (2018). Good and mad: The revolutionary power of women's anger. New York, NY: Simon \& Schuster.

Tronto, J. (1993). Moral boundaries A political argument for an ethic of care. New York, NY: Routledge.

Williams, R. (1977). Marxism and literature. Oxford, England: Oxford University Press. 